科学哲学 31-1 (1998)

$$
\text { デュエムニクワイン・テーゼとポパー* }
$$

立 花 希一

\begin{abstract}
This paper deals with the problem whether Popper's falsificationism has been refuted by the Duhem-Quine thesis. According to the Duhem-Quine thesis it is not an isolated hypothesis but a theory as a whole that is subjected to an experimental test. And it is claimed that by adding an ad hoc hypothesis or by changing a minor auxiliary hypothesis any falsifications of a theory as a whole can be evaded or at least main hypotheses can be saved from falsifications. Against this I claim that it is not always possible to evade the falsifications. Thus Popper's falsificationism has not been refuted by the Duhem-Quine thesis.
\end{abstract}

\title{
1. 問題
}

ここで論じる問題は, デュエムニクワイン・テーゼによってポパーの反証 主義が反証されてしまったのかということである ${ }^{1}$. 野家氏が『科学の解釈 学』(新曜社)において, デュエムニクワイン・テーゼを論ずる文脈の中にポ パーを位置づけて，ポパーの反証主義が反証されたという議論をしておられ る ${ }^{2}$ ので, 先ず氏の見解を取り上げることにしたい（2節）．次に氏の見解を 検討する (3節)，最後に，デュエムやクワインがそもそもデュエムニクワイ ン・テーゼを主張していた（いる）のかという文献学的な問題にも言及する ことにしたい (4 節). 


\section{2. 野家氏の見解}

野家氏は, 科学哲学上の問題の一つである科学と科学でないもの一一氏 言い回しによれば, 科学と物語 (形而上学, 非科学)一との間の境界設定の 問題とその解決案として提出された論理実証主義の検証可能性 （verifiability）の規準とポパーの反証可能性（falsifiability）の規準を取り 上げ ${ }^{3}$, そのどちらもが成り立たないことを, 氏の解釈に基づくデュエム＝ク ワイン・テーゼを用いて論じている．氏の論点はこうである.

論理実証主義者とポパーの主張は共に, 決定実験——論理実証主義者の場 合には「肯定的」決定実験，ポパーの場合には「否定的」決定実験—の存 在を自明の前提として成り立っていた。しかし，決定実験の不可能性を唱え る「デュエム＝クワイン・テーゼ」によってその前提が覆えされるので，そ のどちらも成り立たないことが判明したのだと.そして, デュエムの結論を 引用している。しかし，「物理学理論の真理は，[粒子説と波動説の] いずれ とも決定されない」という，このデュエムの結論だけからは，「理論の検証 (真理性の立証)」が不可能であることを導きだすことはできるかもしれない が，「理論の反証」が不可能であることを導きだすことができないことは容 易に察しがつく，そこで，氏はその反論を予め想定し，次のように主張して いる ${ }^{4}$.

だが，仮説の検証はできなくとも，ポパーの言う反証，すなわち否定 的決定実験ならば成り立ちうるのではないか，と思われるであろう。し

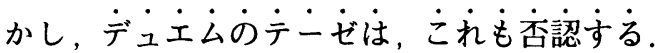

反証，すなわち否定的実験が不可能であることの理由として先ず氏は，実 験にかけられるのが補助仮説や背景知識をも含めた「理論全体」であるとい うデュエムの論点を挙げた後，次のように主張する ${ }^{5}$.

たとえ実験結果が否定的であり，「反例」が見いだされたとしても，理 


$$
\text { デュエムニクワイン・テーゼとポパー }
$$

論にとって末梢部分に属する補助仮説を修正したり，新たにアド・ホッ クな仮説をつけ加えることによって，「理論全体」としてはその反例を 回避することが可能なのである。

そして，そのような事例を科学史から列挙し，最後の結論として「決定実 験は常に後知恵でしかない」というラカトシュ（デュエムでもないし，クワ インでもない！）を引用することによって，文証は不可能であり，したがっ てポパーは間違っていたということを主張するという論旨の展開になってい る.

\section{3. 野家氏の見解の検討}

（1）デュエム=クワイン・テーゼ

氏の見解を検討する前に, デュエムニクワイン・テーゼとは何かというこ とをおさえておく必要があるだろう。実験的テストにかけられるのが個々の 仮説ではなく, 補助仮説や初期条件を含めた理論全体であるという主張があ るが, これが通常, デュエムニクワイン・テーゼと呼ばれるものである。こ の主張からは，理論の反証は不可能であるということは必ずしも帰結しない. デュエムの『物理理論の目的と構造』のII 部 6 章 2 節の見出しでも明白なよ うに，物理学上の実験は理論の全体を偽とする (condemn) 可能性があるこ とはデュエム自身も認めているからである ${ }^{6}$.では3節のデュエムの決定実験 不可能性の議論はどうであろうか.

\section{（2）デュエムの決定実験不可能性について}

氏が引用されたデュエムの主張は, 物理理論の場合, 数学 (幾何学) の理 論とは異なり, 帰謬法によって二つの仮説のうちどちらかを決定的な仕方で 真とするうとはできないという主張である．この意味での決定的実験は，氏 も指摘しているように「肯定的決定実験」と呼ぶことができるであろう.デュ エムによれば，この肯定的決定実験が不可能である理由は, 第三の仮説の可 
能性を想像することが可能だからである. 大方の数学の場合には，矛盾する 二つの命題の証明と反証は対称的であり，一方が真であることを証明すれば 他方は為ということになり，また一方が偽であることを証明（反証）すれば， 帏謬法によって他方が真ということになるが, 物理理論の場合には，その真 理性を打ち立てることができないからであるといゔ‥物理理論に関するデュ エムのこの主張はその通りであろう。しかし，この主張から物理理論の反証 が不可能であるという主張が導き出されるであろうか. 残念ながら，それは 不可能である. 実験によって物理理論の一方を真とすることはできないとし ても,一方, あるいは二つともが実験によって偽となる可能性が存在するか らである ${ }^{8}$. ヤング・フレネルの実験は, 少なくともニュートンの粒子説を反 証したとみなすことが可能であるが, 波動説を反証したとみなすことは不可 能である ${ }^{9}$.この単純な意味で, ヤング・フレネルの実験を（否定的）決定実 験とみなすことができよう. 他方, 波動説の方も, 飛び出す量子のエネルギー が光の強さに無関係であることを示す光電効果に関わる実験によって反証さ れたとみなすことが可能である.

したがって，デュエムによる決定実験の不可能性の議論だけでは，肯定的 決定実験は否認されるとしても，否定的決定実験は必ずしも否認されない.

そこで，氏が次に提出する議論は，II節の最後に引用した文章から明らか なように，いわゆる「約束主義的戦略 (Conventionalist Stratagems)」に 基づくものである ${ }^{10}$. この約束主義的戦略が理論の反証不可能性という氏の 主張の理由になっているので, この戦略を氏は「デュエム＝クワイン・テー ゼ」とみなしているということが判明する ${ }^{11}$.

\section{（3）約察主䔀的戦略}

約束主義的戦略とは，たとえ実験結果が否定的であり，反証事例が見つ かったとしても, 理論にアド・ホックな補助仮説を導入したり, 理論の基本 的定義を秘密裡に変更したり, 実験家の信頼性を疑ったり, 理論を脅やかし ている実験結果の信頼性を疑ったり, 理論家の能力を疑ったり, さらにはど 


$$
\text { デュエムニクワイン・テーゼとポパー }
$$

んな矛盾する証拠に対してもそれを認めることを単に拒否したりすることに よって，理論の反証を回避することが可能であるという主張である．実際， ドグマティックな科学者が批判や反証を真摰に受け取らないということは当 然, 生じる. 例えば, かれはいろいろな約束主義的戦略を用いて, 理論を批 判に対して免疫化することによって反駁を回避しようと努めることができ る。このような約束主義的戦略によって，反証，否定的決定実験は不可能に なるのであろうか, これがまさに争点である.

否定的実験結果によってつきつけられている反証は理論全体であり，その 実験結果と論理だけから反証の原因がどこにあるのかを見いだすことはでき ないという主張をデュエムはしている ${ }^{12}$ が,これはおそらく正しいであろう. 主要でない補助仮説に原因があるかもしれないし，初期条件に詋りがあるか もしれないし，さらには実験結果に誤りがあり，実際には反証結果ではない ということもあるかもしれない.しかし，主要な仮説に誤りがあるかもしれ ないということも可能性の一うとしてある ${ }^{13}$. その際, 理論の修正をまった くせず，ただ単にアド・ホックな仮説をつけ加えることによって反証を回避 することができないことはいうまでもない，例えば，理論全体を Tとし，そ れが反証された場合，そのTを修正しない限り Tは反証されたままであるか ら，それにどんなアド・ホックな仮説をつけ加えたとしてもやはり反証され たままである。したがって，反証に直面した場合，理論のどこかを修正しな ければならないということが要請される。この要請が反証主義の重要な論点 の一つである。しかし，私たちは残念ながら，成功的な修正を発見するため のいわゆる「発見の論理」を持ち合わせてはいない.そこで実験結果と矛盾 する実験予測を導出するのに関わった，理論体系内の個々の仮説の様々な誤 りの可能性を追究し，様々な修正に取り組み，それぞれを新たな理論の構築 の試みとみなし，それぞれに応じて，再び, 経験的テスト，反証の試みにか けようと努力する。これがまさに「推測と反駁」の過程である.

この過程において, 理論の末梢部分に属すると思われる補助仮説を修正す ることによって, 理論を救うことは常に可能であろうか (ここでは「常に」で 
あるかどうかが重要である．もし理論を救うことが常には可能でないとする ならば, 理論全体あるいは主要仮説が反証されたとみなすことができるから である).さて, 実際に補助仮説を修正することによって理論を救うことは容 易なことではないということは明らかであろう．確かに，天王星の変則的な 運行は新たな惑星の発見 (海王星)によって説明することができた。しかし， 水星の変則的な運行はヴァルカン仮説によって救うことができたであろうか. ルヴェリエの戦略は前者では成功したが，後者では成功しなかったのである. したがって，この時点ではニュートン理論を救う手だてが見つかっていな かったわけで，その時点において二ュートン理論は反証されているとみなす ことが可能である. また古代ギリシャ以来, 理論の主要部分であった円軌道 説は救うことができるであろうか，もし反証を回避することができず，反証 可能であるとするならば, 楕円説もまた同様の意味で, 反証可能だというこ とになるだろう。しかも実際，水星の軌道は楕円ではない.

グリュンバウムは, 次のような議論を用いて, 反証回避のために補助仮説 を修正する試みが実際上, 常に可能であるわけではないということを示して いる ${ }^{14}$.

理論 $\mathrm{T}_{1}$ （これは主要仮説 $\mathrm{H}_{1}$ と補助仮説 $\mathrm{A}_{1}$ からなる）から実験結果の予測 $\mathrm{P}_{1}$ がなされ, 他方, 理論 $\mathrm{T}_{2}$ （これは主要仮説 $\mathrm{H}_{2}$ と補助仮説 $\mathrm{A}_{2}$ からなる）か らは実験結果の予測 $\mathrm{P}_{2}$ がなされたが，実験結果としては， $\mathrm{P}_{2}$ ではなく $\mathrm{P}_{1}$ が 確認されたとしょう（因みに, デュエムの意味とは異なるが， $\mathrm{P}_{2}$ と $\mathrm{P}_{1}$ の間に は決定実験がある). 理論 $\mathrm{T}_{2}$ の主要仮説 $\mathrm{H}_{2}$ を反証から回避するためには, $\mathrm{A}_{2}$ に反証の原因を帰し， $\mathrm{A}_{2}$ の代わりに $\mathrm{A}_{3}$ を考客し，しかもそこから $\mathrm{P}_{2}$ ではな く $\mathrm{P}_{1}$ を導出できなければならないことになる。確かに, $\mathrm{H}_{2} \wedge \mathrm{A}_{3} \supset \mathrm{P}_{1}$ を満足 するような $\mathrm{A}_{3}$ は，トリヴィアルな意味では存在する（例えば， $\mathrm{P}_{1}$ を $\mathrm{A}_{3}$ だと みなせばトリヴィアルに $\mathrm{P}_{1}$ を導出することが可能だからである.）しかし， A3はトリヴィアルではない意味では常に存在することが決まっているわけで はないという。したがって，理論 $\mathrm{T}_{2}$ の主要仮説である $\mathrm{H}_{2}$ が実際に反証され る可能性があるとして, ポパーの反証主義を擁護するのである.ここで「ト 
リヴィアルではない意味」というのは，実際にP 1 を導出することのできる A3 考案することは容易なことではなく，しかもそれが実際にできたとして も，その補助仮説もまた主要仮説とは独立にテストされる可能性があり，そ の結果, 反証される可能性があるということである. 先の海王星とヴァルカ ンの例でいえば, 未知の惑星の存在に関する補助仮説はニュートン力学とは 独立にテスト可能であった. そして前者では, 海王星の発見によって天王星 の軌道のずれを説明することができたが, 後者では, ヴァルカンは発見され なかったので, 水星の近日点の移動は説明されず, したがって, 反証された ままであった．このヴァルカンの例は, 補助仮説の導入, 修正によって常 に主要仮説を救うことが可能ではなく, 主要仮説が偽である可能性を示す例 といえよう ${ }^{15}$.

グリュンバウムの議論が正しいとするならば，約束主義的戦略は，トリ ヴィアルな意味では真であるかもしれないが, トリヴィアルではない意味で は真ではないことになる，さて，科学者が理論の反証に直面した場合，その 理論の反証を回避できる可能性があることを指摘するだけで済ますことはで きるであろうか. 科学者は, 具体的に補助仮説を修正するなり, 主要仮説を 修正するなり，あるいは全く新たな仮説を考案することによって，反証が実 際に克服されるような理論を提出することが要請されているのではなかろう か. すなわち，例えば，実際にA ヴィアルな作業ではないことは明白であろう. 理論を救う手だてが実際に考 案されない限り, 理論は反証されているとか, あるいは少なくとも反証の危 機にさらされていると判断することができるが，この判断は後知恵とはいえ ないであろう．そして，反証の危機を直視することが批判的合理性にとって 必要な条件であり，しかも知識の成長にとっても必要な条件である。それは 矛盾（反証）の認知およびその克服の試みが合理性の要だからである.

4. デュエム=クワイン・テーゼ ?

デュエムとクワインは，反証主義を否定するようなデュエム＝クワイン． 
テーゼを主張していた（いる）のであろうか.

グリュンバウムはデュエムを対象にして批判を展開しているが，ところが， 当のデュエムは，そのような主張をしているわけではない. デュエムは次の ように述べている ${ }^{16}$. いくつか列挙すると，

実際，普遍的に受け入れられる規約と化した仮説……を，永遠に確 かなものと信じないように十分注意しなければならないであろう.物 理学の歴史がわれわれに示すところによれば, 人間精神は, 何世紀も の間, 共通に一致して不可侵の公理とみなされてきた原理をかなりし ばしば全面的に覆し，物理理論を新たな仮説の上に再建するよう促さ れてきたのである。

「われわれは，それがいかに厳密な実験であろうとも，ある新たな実 験のせいで当の仮説を放棄するに至るということは決してないであろ うと確信する」などと発言するのは極めて不用意なことである.

このこと [力学の原理や倍数比例の法則などを直接的な実験的テスト にかけようとすることは馬鹿げているということ］から，直接的な実験 による反証の及ばないところに置かれている仮説はもはや実験を恐れる 必要は全くないということが帰結するのだろうか.こういった仮説は， 事実の観察がわれわれに与えてくれる発見がどのようなものであれ，不 変のものであると保証されるのであろうか. そう主張するとすれば, 深 刻な誤りを犯すことになるであろう.

理論の目的は経験法則を表象することである。このような理論は本質 的に事実と照合されるように定められた図式である.ところが，この照 合が，ある日，以下のことを告げる，すなわち，われわれの図式を複雑 にする諸々の修正では, この図式と事実との間の満足な一致をもたらす 


$$
\text { デュエムニクワイン・テーゼとポパー }
$$

には十分ではないということ，そして，長い間，異論なく受け入れられ てきた理論が放棄されねばならないということ，したがって全く異なっ た理論が全面的に新しい仮説に基づいて構成されなければならないとい うことを告げる，ということが十分ありうる．その日には，単独に取り あげられる限り経験の直接的反証に耐えてきたわれわれの仮説のうちの 一つが，全体としての体系がもたらす諸帰結に対して現実 [実在] が押 しつける反証の重みに耐えかねて，それが支える体系とともに崩壊する ということになる.

すなわち，物理理論は全体として反証可能であるし，歴史的に，実際，反 証されてもいるというのである。もしデュエムが今生きていて，約束主義的 戦略が自分に帰せられていることを知ったら，何というであろうか.

では, クワインの方はどうであろうか.クワインが「ホーリズム」を主張 し，しかもその先駆者であるとしてデュエムに言及したことによって ${ }^{17}$, デュエムニクワイン・テーゼとして知られるようになった自分の論文，「経 験主義の二つのドグマ」を回顧して,「私が後悔していることの一つは, 不 必要にホーリズムの強い主張をしてしまったことである」 ${ }^{18}$ と述べ,「二つの ドグマ」の中のよく引用される有名な箇所を自ら引用し, 次のように述べて いる。

経験的に有意味な単位は科学全体である。…․゙とんな言明でも，も しわれわれが体系の中のどこか他のところで十分徹底的な調整をする ならば，どんなことが起きようとも，真理を保持しうる……逆に，ど んな言明も改訂を免れないのである。

これは確かにある種の形式主義的な法律上のいい方においてはもちろ ん正しいが，しかし，これはより重要な論点から注意をそらすものであ る……後の著作において, 私は科学の全体ではなく, 科学の塊り 
（chunk）に訴えた。科学の塊りとは, 意㙅の臨界量を十分に含んでいる 文の集合体 (cluster) のことである。これによって，私が意味している ことは, 観察可能な実験条件に基づく観察可能な結果を含意するのに十 分な大きさの集合体である.

現在では,私はこの問題を観察定言文 (observation categoricals) と 私が呼ぶ用語で定式化している，観察定言文というのは，「これのとき は, いつでもあれ」という形の一般化である.ここでは,「これ」と「あ れ」とが観察文に相当する。…文の集合体は，もし観察定言文を含意 するならば，意味の臨界量をもっているといえる，そして，文の集合体 の実験的チェックは，観察可能な条件節の条件を整えたうえで, 帰結節 が実現するかどうかを見極めることによって，含意された定言文をテス トすることからなるのである.

要するに,「全体」というものが, 実験的テストが十分可能な程度の集合体 に縮小されているのである。そして，この考えをかれは「穏健なホーリズム (moderate holism)」と呼び ${ }^{19}$ ，さらにはその文の集合体が実験によって庈 駁される (refuted) 場合についても言及し, その場合，さらなる進歩を最適 化するような仕方で選択するという希望をもって, 集合体の文を棄却したり することによって解決されるというのである.この穏健なホーリズムが反証 主義を否認するものではないことは明らかであるように思われる．

結局, デュエムと（少なくとも現在の）クワインは両方とも，反証主義を 否定するようなデュエム=クワイン・テーゼを主張してはいないのである!

注

*書き改める以前の抽稿に対して貴重なコメントをしてくださった本学会の匿名 のレフリーに対して，謝意を申し上げたい，また貫重なアドバイスをしてくだ さった鹿児岛大学の小河原誠氏と南山大学の小林傅司氏にも謝意を申し上げた い.しかし把稿に誤りがある場合，その責任が箨者にあることは当然のことであ る. 
1.この問題を考察することになったのには経緯がある. 1995 年11月 19 日, 本 学会の第 28 回大会において,「ピエール・デュエムの科学哲学の現代的意義」 というテーマのワークショップが大阪市立大学の小林道夫氏がオーガナイザー となって開催された. 私のイスラエル留学中の恩師であるアガシがしばしばポ パーとデュエムを対比させながら科学哲学を論じているので, 私はポパーと デュエムの関係について非常に興味をもっていた。前もって送っていただいた 資料の中に，野家氏の著書のコピーの一部が入っており，そこではポパーが言 及されて論じられていた。 ところが，ワークショップではオーガナイザーを含 めどの提題者からも，一度もポパーに関する発言がなかった．新科学哲学の流 れに関する話題の中で, クーン，ラカトシュ，ファイヤアーベントは言及され たにもかかわらずである。あたかもポパーはかれらによって批判され，ポパー の反証主義は反証されてしまい, 過去のものになってしまったかのようである. ポパーの反証主義は, 科学哲学において有力な二つの立場であった, 帰納主義 と約束主義を批判的に検討していく中で, それらに代わる第三の立場として提 起された科学方法論である.ポパーの反証主義には問題点がいろいろあるにし ても傾聴に値する科学哲学であると評価している筆者としては非常に残念で あった。

ポパーの議論をきちんと検討し，評価する試みの一環として，ここではデュ エムニクワイン・テーゼに的を絞って，ポパーの反証主義との関係を見極めた いと思う次第である。

2. 本学会誌『科学哲学』 29 揭载の「「デュエムニクワイン・テーゼ」をめぐって 一小林道夫氏への手紙一」においても, 野家氏はかれの著書「科学の解䣋学」と 同様，反証されたという議論をしておられる，この論文は「小林道夫氏への手 紙」の体裁をとっており, しかも小林道夫氏の著書『科学哲学』, 産業図書, 1996 年の批判でもあるので, この論文に対する返答は小林氏におまかせすることに し, 本稿は野家氏の著書に絞って検討させていただいた。但し，小林氏は，この 著書の中で, デュエムの主張を若干留保することによって, 反証主義と両立する 方向の議論をしており，次のように述べている．「物理学においては決定的実験 はありえないということがあら்る場合に主張されるならば,それも物理学の歴 史の実状に合致しないと思われる」と（115頁，傍点は原文). 私はこの主張に 全面的に賛成であることを申し添えておきたい(因みに, 私が小林氏の著書を入 手し, 読ませていただいたのは, 拙稿が一旦完成した後の 1997 年 6 月 27 日のこ とである).

3. 論理実証主義が検証可能性説によって解こうとした問題と，ポパーが立てた問 題である境界設定の問題とが同じ問題であったかどうかについて疑問の余地があ るが, それについては問わないことにする.またポパーが境界設定の規準によっ て，科学と科学でないものを「峻別」(154 頁)しようとしたかどうかについて も疑問の余地がある（野家氏はそこではポパーの名前を出してはいないけれど 
も).私見では，ポパーの境界設定の規準は「大雑把（rough）」なものであり， また境界設定の問題は, 帰納の問題あるいは学習 (知識の獲得・成長) の問題と 比べればそれほど重要な問題ではないと考えている.また反証主義は境界設定の 問題の解決案としてというよりはむしろ後者の問題の解決案として考えた方が興 味深いと考えているが，こうした事柄については別の機会に論ずることにした い.ポパーの境界設定の規準が「大雑把」なものであることは，神野慧一郎氏も， ポパーの言葉を引用しながら強調されている。「ポパー研究会講演草稿」、「ポ パーレター」, 日本ポパー哲学研究会, Vol. 7, No. 2, 1995 年 12 月, 25 頁.

4. 野家啓一、「科学の解釈学】, 新曜社, 1993 年, 151頁. 傍点は引用者.

5. 同上，151頁．傍点は引用者によるが，ここが争点になると思われる．後で詳 しく考察することにしたい.

6. Pierre Duhem, The Aim and Structure of Physical Theory, Athenam, New York, 1981, p. 183. 邦訳, ピエール・デュエム、『物理理論の目的と構造』，小 林道夫，熊谷陽一，安孫子信訳，勁草書房，1991年，247頁。ここでは詳説す るゆとりはないが, ポパーは，理論の解釈には，約束主義的解釈と経験主義的， 反証主義的解积という少なくとも二つの解釈の可能性があることを指摘している が，ひとたび反証主義的解釈を採用すれば，論理上の反証可能性を維持すること ができると思われる，この点については，拙稿，「約束主義的解釈と約束主義的 戦略」、「ポパーレター』, 日本ポパー哲学研究会, Vol. 9, No. 1, 1997 年 5 月,1113 頁. 因みにポパーは，デュエムを約束主義者の一人に挙げているが，約束主 義的解㹞をするような約束主義者ではない（Pierre Duhem, op. cit., pp. 2126. 邦訳，287-92頁)。ひとたび反証主義的解袂を採用した後の，単純な個別的な 仮説の場合ともっと複雑な理論体系の場合における反証可能性の詳細な考察につ いては, Gunnar Andersson, Criticism and the History of Science, E.J.Brill, Leiden, 1994, pp. 11-21参照。私はAndersson による反証主義（かれは「批判 的反証主義」と呼ぶ）の擁護に基本的に賛成であり，しかもかれから多くのこと を学ばせていただいた．さらにかれからは，後で言及するクワインの論文（かれ の著書で言及されていたもの)をわざわざ送っていただいた.ここに謝意を表す る次第である. (I would like to express my gratitude to Professor Gunnar Andersson for his book and his sending me a copy of Quine's paper.)

7. 数学の場合にも，帰謬法が無条件で成立するかどうかについては議論の余地が ある.帰謬法を用いるには排中律が必要であるが，それを認めない論理学の立場 もあるからである。

8. 正確には，実験によってではなく，実験結果（あるいは観察）を言語によって 定式化した言明と仮説が矛盾し, 前者を真であると仮定するならば, 後者の仮説 は偽となるということである.これは, 演繹的に妥当な偽の逆転送というメタ規 則に基づいている. 因みに, 論理実証主義の検証可能性は論理的にも不可能で ある. 実験言明ないし観察言明と仮説が矛盾しない場合でも，そのことによって 


$$
\text { デュエムニクワイン・テーゼとポパー }
$$

仮説が真であるという結論は下せないからである.この論理的な場面における原 理的な反証の可能性と，他方，検証の不可能性は無視すべきではないように思 われる.この非対称性を明確に主張したのがポパーであり，したがって，ポパー が，決定実験の不可能性によってデュエムは検証の不可能性は立証したが，反証 の不可能性は立証していないと主張することには一理ある.K. R. Popper, Conjectures and Refutations: The Growth of Scientific Knowledge, Routledge \& Kegan Paul, London, 1963, p. 112, note 26. デュエムはこの非対称性を当然 知っていたかもしれないが, 決定実験における反証の可能性（あるいは反証の不 可能性）について明確には述べていないからである. 論理上の「反証可能性」な いし「反証」と, 実際上の「反証可能性」ないし「反証」との明確な区別につい ては, K. R. Popper, Realism and The Aim of Science, Hutchinson, London, 1982, Sec. 22, pp. 181-9. 参照. また, 反証主義を批判（否定）したとされる クーンですら，次のように明言している。「「探究の論理」の中で，カール卿は， 経験的証拠に対する関係における一般言明とその否定との非対称性を強調した. 科学理論は，そのあらゆる可能な事例にうまく適合するということは立証しえな いが，ある事例にはうまく適合しえないということを明らかにできる。この論理 的自明の理とその含意が強調したことは，一歩前進であり，そこから後退しては ならないものだと私には思われる」と. Thomas S. Kuhn, Logic of Discovery or Psychology of Research?, in Criticism and the Growth of Knowledge, edited by I. Lakatos and A. Musgrave, Cambridge University Press, London, 1970, p.13.

9. デュエムはフーコーに言及し，「そこからはフーコーとともに，放射理論体系 は事実と両立しないということを結論づけることが可能である」（P i e r r e Duhem, op. cit., p. 187. 邦訳，251頁）と述べているが，これは放射理論体系 が, ポパーの言葉でいえば, 反証可能であることの指摘である. ポパーの反証可 能性説は, 個々の仮説（例えば, 単純な経験的一般化）の反証可能性だけではな く, 理論体系（the whole system）の反証可能性についても当初から述べてい る. K. R. Popper, The Logic of Scientific Discovery, Hutchinson, London, 1959, p. 76 参照. ポパーがデュエムの著作を独語版で熱心に研究した節がある ので,ここでのポパーの発言とデュエムとの相違は微妙であるが, ポパーが反証 とそのポジティヴな意義を強調し，反証可能性を中心に据えた科学方法論を展 開したのに対して, デュエムはそうしていないという点に相違がある.デュエム は物理理論を, 分解することによって故障を特定できる時計にではなく, 解剖の できない病人に例えている（Pierre Duhem, op. cit., pp. 187-8. 邦訳, 252-3 頁）が, ポパーは, 病人の場合でもいわば胃カメラやCTスキャンなどを用いて 病巣をできる限り特定化することができるし，しかもそうすべきであると主張す るであろう. K. R. Popper, Realism and The Aim of Science, pp. 187-9参照.

10. 様々な反証回避策を「約束主義的戦略」と名づけたのも，ポパー自身である. 
しかもこの約束主義的戦略を承知したうえで，ポパーが反証主義を提唱していた という事実は注目に値するように思われる。

11.この戦略をデュエムやクワインが主張しているかどうかということについて は，4節で検討することにしたい。

12. Pierre Duhem, op. cit., p. 185. 邦訳, 249 頁.

13. 約束主義的戦略として解积した場合のデュエムニクワイン・テーゼは，この可 能性を否定する。様々な約束主義的戦略を用いることによって，常に主要な仮説 を救うことができると主張しているからである。それに対して反証主義は，常に というわけではないと主張する。

14. Adolf Grünbaum, The Duhemian Argument, in Can Theories Be Refuted?, ed. by Sandra G. Harding, Reidel, Dordrecht, 1976, pp. 116-31. 記号表現は 若干変更した。

15.ルヴェリエその他の科学者は，主要仮説であるニュートンの万有引力の法則な どを維持したままで, 太陽と水星の間の小惑星説や, 太陽の扁平率から生じる可 能性説など補助仮説の変更を提案をしたが, いずれも失敗した。 その結果, 主要 仮説に疑いが向けられるようになっていった. N. R. Hanson, Leverrier: The Zenth and Nadir of Newtonian Mechanics, ISIS, 53, 1962, pp. 359-78参照. 反証主義の観点からみれば，1849年，ルヴェリエによって水星の近日点の移動 が公表されて以来, ニュートン理論は反証の危機にさらされたのであり，それを 説明しようとして考案されたニュートン理論のさまざまなバージョン(ヴァルカ ン説も含む) はそれぞれ反証されたと科学者はみなすべきなのである.John D. Greenwood, Two Dogmas of Neo-Empiricism, Philosophy of Science, 57, 1990, pp. 565-6, およびアブラハム・パイス著「神は老獊にして・・アインシュタイ ンの人と学問」, 産業図書, 1987 年も参照のこと.

16. Pierre Duhem, op. cit., p. 212, p. 215, pp. 215-6. 邦訳, 286-7 頁, 287-8 頁，291頁，292頁. また, クワインがグリュンバウムの批判に対して答えてい る短いコメントも注目に值する。「デュエムニクワイン・テーゼをトリヴィアル でないものとみなした場合には維持できないというあなたの主張は説得力がある と思う.... 私としては，私が用いたテーゼはおそらくトリヴィアルなものであ るといいたい」と全面的に譲歩しているとも受け取れる発言をしている．W. V. Quine, A Comment on Grünbaum's Claim, in Can Theories Be Refuted?, p. 132. このコメントは, グリュンバウムの別の論文についてのものであるが，グ リュンバウム自身も註（p. 178）で断わっているように，先の論文と基本的に同 じ議論が展開されている. Adolf Grünbaum, The Falsifiability of Theories: Total or Partial? A Contemporary Evaluation of the Duhem-Quine Thesis, in Boston Studies in the Philosophy of Science, Vol. I, ed. by M. Wartofsky, Reidel, Dordrecht, 1963, pp. 178-95.

17. W. V. Quine, Two Dogmas in Retrospect, Canadian Journal of Philoso- 


$$
\text { デュエム=クワイン・テーゼとポパー }
$$

phy, Vol. 21, No. 3, 1991, p. 269 で, 「二つのドグマ」の注の中で, デュエム が言及されていることに触れ，当時はデュエムを知らなかったが，後にC．ヘン ペルと P. フランクによって関心を促され，『論理学的観点から」を出版する際 に，デュエムを挿入したのだと述べている。

18. Ibid., p. 268. 傍点は原文イタリック.

19. Ibid., p. 269. また 1992 年に出版されたクワインの著書, Pursuit of Truth, Harvard University Pressにおいてもクワインは「穏健なホーリズム」を主張 している（pp. 13-6）。さらにはポパーに言及し，ポパーの反証主義を支持する 議論まで行っている（pp. 12-3）.

(秋田大学 ·倫理学) 